\title{
Assessment of stem cell carriers for tendon tissue engineering in pre-clinical models
}

\author{
Sunny Akogwu Abbah ${ }^{1}$, Kyriakos Spanoudes ${ }^{1}$, Timothy O'Brien², Abhay Pandit ${ }^{1}$ and Dimitrios I Zeugolis ${ }^{\text {* }}$
}

\begin{abstract}
Tendon injuries are prevalent and problematic, especially among young and otherwise healthy individuals. The inherently slow innate healing process combined with the inevitable scar tissue formation compromise functional recovery, imposing the need for the development of therapeutic strategies. The limited number of low activity/reparative capacity tendonresident cells has directed substantial research efforts towards the exploration of the therapeutic potential of various stem cells in tendon injuries and pathophysiologies. Severe injuries require the use of a stem cell carrier to enable cell localisation at the defect site. The present study describes advancements that injectable carriers, tissue grafts, anisotropically orientated biomaterials, and cell-sheets have achieved in preclinical models as stem cell carriers for tendon repair.
\end{abstract}

\section{Introduction}

Large tendon injuries that necessitate surgical intervention are of significant concern not only among athletes, but also in the general population. These injuries are often associated with prolonged disabilities that require long treatments and painful rehabilitation periods. Functional recovery is often incomplete, leaving the patient with life-long joint instability, which frequently result in arthritis [1]. Expectedly, this has serious social and economic implications. Specifically, an estimated 30 million cases of tendon and ligament injuries are seen worldwide annually, leading to extensive loss of man-hours [2]. The annual USA expenditure is estimated at US $\$ 30$ billion, whilst European healthcare expenditure exceeds $€ 115$ billion per year [3,4]. The increasing return of people to various rigorous sporting activities after decades of

\footnotetext{
* Correspondence: dimitrios.zeugolis@nuigalway.ie

${ }^{1}$ Network of Excellence for Functional Biomaterials (NFB), Bioscience Building, National University of Ireland Galway (NUI Galway), Galway, Ireland Full list of author information is available at the end of the article
}

sedentary lifestyle, coupled with the increasing life expectancy, is expected to further increase tendon injury incidents, putting a further financial strain on healthcare systems [5].

The limited number of low activity/reparative capacity resident cells in tendon tissues has been postulated to be the main culprit for the restricted regenerative capacity of tendon tissue [6-10]. Cell-based therapies promise to recapitulate essential biological processes of neonatal tendon development that would culminate in the regeneration of fully functional neo-tendon tissue. Indeed, cell-based tissue engineering strategies have witnessed a drift from an era focused primarily on feasibility studies to an era focused on optimisation and specific engineering of the implantable tissue constructs, appraised alongside therapeutic efficacy and safety [11-14]. This progress has come in parallel with increasing understanding of the intricate molecular mechanisms underlying the therapeutic potential of stem cells and their physical environment in different tissues [15-19]. Current evidence indicates that the therapeutic efficacy of stem cells relies heavily on their capacity to secrete a spectrum of bioactive/trophic molecules, with an extensive range of functions, including chemo-attraction, immunomodulation, angiogenesis, antiscarring and anti-apoptotic properties [20-22]. In a sense, this stem cell pool will act as a biological factory designed and built to function as a production line for progenitor cells and/or bioactive molecules, until differentiation towards the host tissue lineage occurs. It is therefore imperative to ensure optimal residency of viable and potent stem cells at the site of injury that will ultimately enable recapitulation of native cellularity back to normal, pre-injury levels.

The major obstacles to direct cell injections are the localisation of the cell suspension at the target tissue, optimum timing of injection with respect to different healing stages, and maintenance of control over cell fate and functionality [23-26]. From a surgical perspective, stable fixation of any implanted graft is of paramount importance to avoid disruption under the dynamic 
mechanical environment native to the tendon. Although in equine patients anatomic characteristics and injury type preponderance $[27,28]$ allow treatment of small defects in superficial digital flexor tendon with intratendinous injections, even with a small number (as low as $645,000)$ of bone marrow-derived mesenchymal stem cells (BMSCs) [29-31], the complexities of human tendon injuries often call for surgical debridement and implantation of a mechanically resilient three-dimensional scaffold that will sustain the mechanical loads of the local environment until definitive healing takes place. To this end, delivery of an appropriate cell population using injectable hydrogels, autologous, allogeneic or xenogeneic tissue grafts, anisotropically ordered biomaterials, or cell sheets, with localised and sustained delivery of bioactive/therapeutic molecule capacity (Figure 1), is at the forefront of academic, clinical and industrial investigation for tendon tissue engineering [32-37]. Here, we discuss the effectiveness demonstrated in tendon preclinical models of various stem cell populations and carrier systems.

\section{Injectable stem cell carriers}

Minimally invasive injectable carriers, based on natural or synthetic polymers, are often utilised as carriers for localised and controlled release of cells along with bioactive/ therapeutic molecules in musculoskeletal repair. Such systems protect cell membranes from rupture during injection and facilitate prolonged cell survival and maintain cell functionality at the harsh injury environment, while the presence of functional moieties responsive to specific stimuli allow spatiotemporal release of their cargo, and the fast in situ self-assembly rate ( $<10$ minutes) enables conformity with the injury site and direct integration with the host tissue [38-47]. Fibrin- and collagen-based hydrogels dominate in the tendon repair field. Both are naturally occurring materials characterised by low antigenicity and immunogenicity, and their inherent properties, such as cell recognition signals that promote cell attachment, migration and growth that stimulate tissue healing and regeneration, their ability to form scaffolds of different conformations with high tensile strength, and their

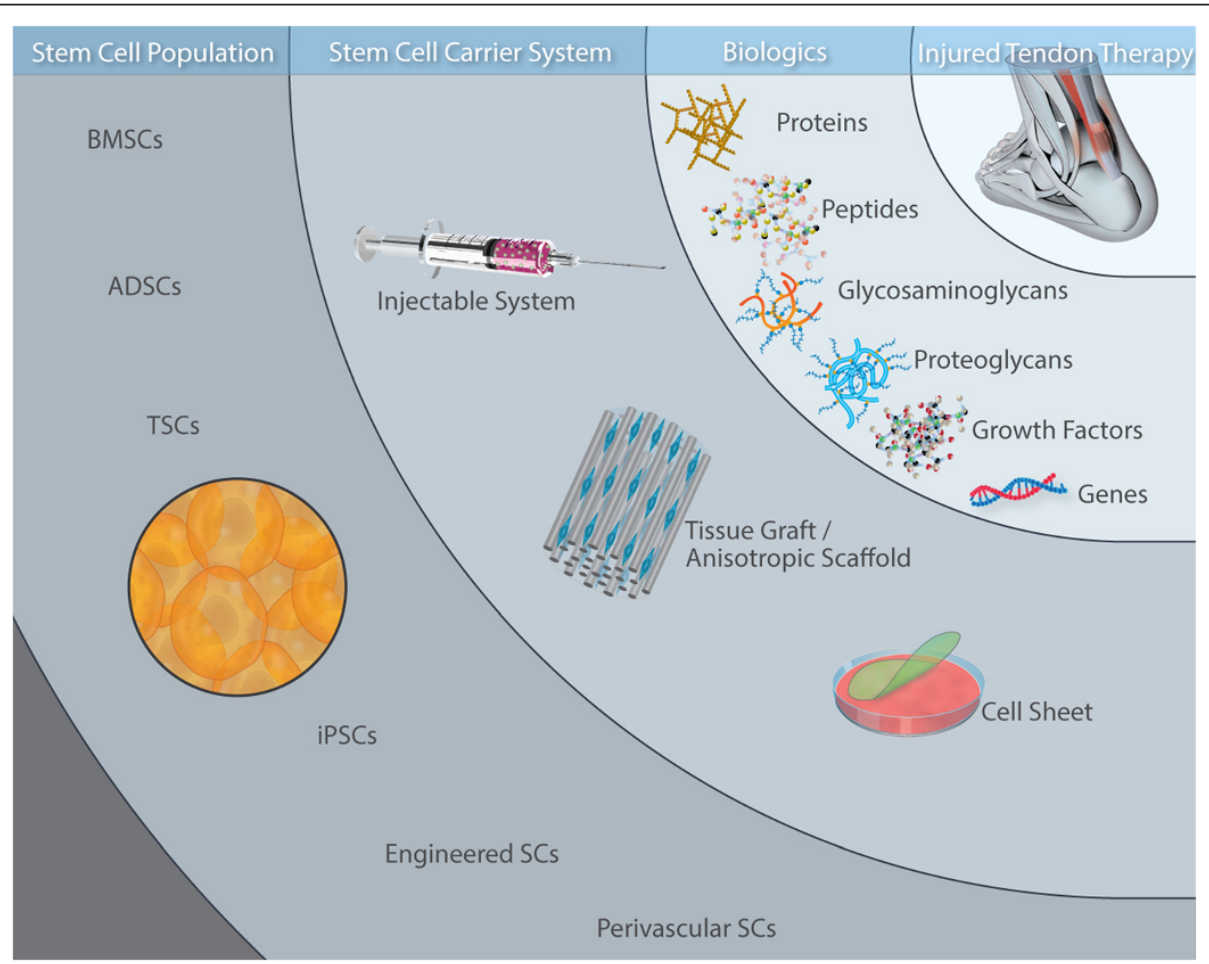

Figure 1 The tendon repair and regeneration toolbox. Advancements in cell biology have made available a number of stem cell populations for tendon repair. Injectable carriers can act as stem cell carriers with potential to enhance clinical outcomes, especially in small defects. This strategy also offers the benefit of being minimally invasive, which is of critical importance, particularly for repeated or staged cell transplantations. Tissue grafts and anisotropic scaffolds are favoured for large tendon injuries. Such systems mimic the biophysical milieu of native tendons, offer an excellent three-dimensional environment for cell infiltration and growth, and facilitate directional cell growth and new tissue formation in vivo. Although cell-sheets have not taken off for tendon repair, preliminary results are very promising indeed and we anticipate their efficacy to be investigated further in the future, either alone or in combination with a carrier system that would provide adequate mechanical properties, whilst preserving cell phenotype for the period required to develop the implantable device. The therapeutic potential of the carrier systems can be further enhanced using bioactive/therapeutic molecules; controlled release capabilities amplify the in vivo potency of the implanted cells, whilst positively interacting with the host. ADSC, adipose-derived stem cell; BMSC, bone marrow-derived mesenchymal stem cell; iPSC, induced pluripotent stem cell; SC, stem cell; TSC, tendon stem cell. 
therapeutics delivery capacity, further advocate for their use as biomaterials [48-52].

Fibrin-based hydrogels that allow homogenous BMSC distribution have been used in a rabbit Achilles tendon transaction model, resulting in improved collagen fibre organisation and increased mechanical properties at an early time-point (3 weeks post-implantation). This functional improvement was, however, transient as it was lost 6 weeks later, coinciding with fibrin degradation [53]. Whether enhanced fibrin stability (prolonging its cell immobilisation capacity) will lengthen the in vivo therapeutic effectiveness is yet to be seen. This study contradicts earlier work demonstrating that fibrin glue has the potential to maintain BMSC viability within rabbit patella tendon defects for at least 8 weeks post-implantation [54]. Another study, in a rat patellar tendon defect model, demonstrated that liquid fibrin loaded with either BMSCs or human fibroblasts results in a more mature tissue formation with more regular patterns of cell distribution $[55,56]$. Contrary to these findings, implantation of fibrin glue loaded with BMSCs in a rat rotator cuff tendon defect model concluded that although the cells were present and metabolically active for the duration of the study (4 weeks), they did not improve the structural characteristics nor the strength of the neotendon [57]. The above results indicate that although fibrin is a suitable carrier for BMSCs (presumably because of its ability to form clots), its suitability for tendon repair is inconclusive and may largely depend on the site and type of injury.

Collagen-based hydrogels have also been used extensively as injectable stem cell carriers for tendon repair [55]. When collagen type I was loaded with rabbit BMSCs and implanted into a rabbit patellar tendon defect, significant biomechanical improvements were observed within 4 weeks post-implantation; however, no histological or morphometric differences were observed between the BMSC-loaded and BMSC-free groups [55]. In a more recent study, a rabbit Achilles tendon repair model was used to assess the influence of the collagen hydrogel to autologous rabbit BMSC ratio on tissue repair [56]. The results indicate that higher cell-tocollagen ratios jeopardise the structural integrity of the gel in vitro to such an extent that it may become practically unusable in vivo. Therefore, the in vivo effect of high cell-to-collagen ratios could not be directly compared to low cell-to-collagen ratios in that study. However, in vivo results obtained 12 weeks after implantation of relatively low cell-to-collagen ratio (that is, low cell density) constructs showed no dose-dependent decline in biomechanical competence and histological appearance of the treated tendon defects. This study therefore indicates that the cell-to-vehicle matrix ratio is an important parameter for construct fabrication in cell-based functional tendon tissue engineering.
Platelet-rich plasma (PRP) when mixed with thrombin will clot and thus can be used as an injectable cell carrier. The additional high growth factor content makes it an attractive material for musculoskeletal repair [58-60]. Functional evaluation of PRP/adipose tissue-derived stem cell (ADSC) gels implanted in a rabbit Achilles tendon defect model revealed increased tensile strength compared to PRP gels alone [61]. Similarly, injured rat Achilles tendons treated with PRP/tendon stem cells (TSCs) showed a synergistic healing effect based on molecular level analysis of tendon-related genes [62]. However, the presence of transforming growth factor- $\beta$ in PRP may be more pathogenic than reparative, as it has been shown to drive the differentiation of various stem cells towards bone and cartilage lineages [63-68]. Numerous studies have also discussed the controversial results of PRP treatment in orthopaedic practice [69-71]. In accordance with previous observations [72,73], we believe that although $\mathrm{PRP} / \mathrm{stem}$ cell systems may have great potential in tendon repair, thorough analyses, along with long-term preclinical studies, should be carried out to safely determine the clinical potential of this therapy. This is particularly important based on recent studies indicating that a high concentration of leukocytes in PRP results in persistent expression of inflammatory cytokines and is associated with scar tissue formation [74].

Overall, injectable carriers provide a conducive threedimensional environment for stem cell proliferation, differentiation, migration and growth. Such carriers have potential in treating small injuries and for controlled/ localised delivery of cells and biologics. However, such semi-solid systems are not suitable for large tendon defects, where structural integrity is of paramount importance.

\section{Tissue grafts as stem cell carriers}

Tissue grafts, such as palmaris/plantaris longus or semitendinosus-gracilis autografts and Achilles tendon, rotator cuff allografts or xenografts, are currently considered the gold standard in clinical practice, given their almost identical structure and composition to the injured tendon tissue. Furthermore, their rapid fixation capability, fast healing rate and almost normal tissue ingrowth in both preclinical animal models and human clinical studies have led to the commercialisation of several products [75]. In an attempt to identify an ideal cell population to complement tendon healing induced by acellular tendon grafts, epitenon tenocytes, tendon sheath fibroblasts, BMSCs and ADSCs were assessed by histological analysis in a rabbit flexor profundus tendon defect model [76]. Although no differences were observed between the different cell populations, all recellularised graft groups showed improved histological characteristics compared to control acellular grafts. Histological and biomechanical analysis of rabbit 
Achilles tendon allografts loaded with BMSCs for anterior cruciate ligament (ACL) reconstruction strongly showed that they resembled normal ACL insertion and exhibited significantly higher failure loads than their control counterparts [77]. Although this study showed that exogenously loaded mesenchymal stem cells enhanced the healing process of allografts at the insertion site, mid-substance construct rupture was observed during mechanical testing. From a clinical perspective, however, a major bottleneck associated with ACL repair is the restoration of normal tissue characteristics at the insertion site; this bottleneck is attributable to tunnel geometry and inhomogeneity of the graft-tunnel interface [78]. This has motivated the development of multiple surgical techniques to improve healing. In a rat tendon-bone healing model, histological analysis demonstrated that Achilles tendon grafts loaded with synovial mesenchymal stem cells accelerated early remodelling, highlighting the inherent reparative potential of mesenchymal stem cells [79]. Similarly, ACL-derived stem cell sheets (CD34+ cells) rolled around allogeneic tendon tissue demonstrated histological and biomechanical benefits in a rat ACL reconstruction model $[80,81]$. Recently, alternative approaches, such as in vitro expansion of TSCs/ADSCs on self-assembled or engineered tendinous matrices and allografts, have been reported [82-84]. These efforts aim to stimulate the proliferation of TSCs and to promote differentiation of ADSCs towards the tenogenic lineage for eventual in vivo application. Given that tissue grafts continue to hold clinical appeal, advancements in decellularisation techniques that promote preservation of the extracellular matrix composition and lower graft versus host reactions will help to hone tissue grafts into efficient stem cell carriers.

\section{Anisotropically ordered materials as stem cell carriers}

Biomaterial-based graft substitutes for the treatment of tendon and ligament injuries provide the opportunity to avoid the morbidity issues associated with autografts [85-87]. They are particularly important in degenerative [88-91] or congenital $[92,93]$ conditions, where autografts are not available in sufficient quantities. Tendons are dense connective tissues consisting primarily of type I collagen arranged in a hierarchical order: tropocollagen molecules (approximately $1.5 \mathrm{~nm}$ in diameter) are packed closely together to form fibrils (approximately 80 to $100 \mathrm{~nm}$ in diameter), fibres (approximately 1.0 to $30 \mu \mathrm{m}$ in diameter) and fibre bundles (approximately 1,000 to 3,000 $\mu \mathrm{m}$ in diameter), which ultimately form the tendon unit [94-98]. Although numerous material-based tendon equivalents have been developed over the years, fibrous constructs (made through wet spinning [99-103], isoelectric focusing [104-106] or dry spinning [107-112] processes) lead the race in maintaining tendon cell phenotype, induction of tenogenic differentiation of progenitor cells, tendon regeneration and functional recovery in relevant in vivo models. This is attributable to the specific hierarchical order of the tendon unit. Indeed, such scaffold conformations provide topographical, spatial, chemical and immunological control over cells. They also provide mechanical stability/integrity for large tendon defects and a template for the organisation of the neotendon tissue. Although dry spinning has been shown to denature the triple-helical conformation of natural biopolymers $[113,114]$, it has been extensively used, with profound success, as a stem cell carrier with synthetic polymers. In a large rotator cuff rabbit model, electro-spun polyglycolic acid fibres loaded with autologous BMSCs exhibited not only a higher type I to type III collagen ratio, but also significantly improved tensile strength compared to the control groups at 16 weeks post-implantation [115]. A knitted polylactide-co-glycolide micro-fibrous construct loaded with allogeneic rabbit BMSCs and implanted in a rabbit Achilles tendon model demonstrated similar histological results to the construct alone and native tendon repair. However, the tensile stiffness of BMSC-seeded constructs was only $87.0 \%$ of that of the normal tendon and the modulus was only $62.6 \%$ of that of the normal tendon [116].

To further enhance stem cell retention on fibrous materials, composite implantable devices based on a hydrogel stem cell carrier and a fibrous load-bearing structure have been assessed. In a rabbit Achilles tendon repair model, pre-tensioned polyglyconate sutures loaded with autologous rabbit BMSCs in contracted collagen gel demonstrated significantly improved cellular organisation, extracellular matrix organisation and biomechanics [117]. In a patellar tendon repair model, polyglyconate sutures loaded with autologous rabbit BMSCs in contracted collagen gel demonstrated significantly higher mechanical properties than the naturally repaired counterparts, whilst no significant differences in cellular organisation or histological appearance were observed between the groups at 12 and 26 weeks post-surgery [118]. Electro-spun polylactide-co-glycolide scaffolds, loaded with heparin/fibrin hydrogel, ADSCs and platelet derived growth factor $\mathrm{BB}$ demonstrated improved tendon healing in a dog model of transected flexor digitorum profundus tendons [119]. Collectively, these studies show that aligned fibrous scaffolds that closely imitate the architecture of tendon tissue offer structural and mechanical benefits, along with an instructive physical environment that guides new functional tissue development. However, such carriers alone are insufficient for complete recapitulation of tendon function. Functionalisation with a hydrogel that would enable localisation/retention of seeded cells and spatiotemporal release of vital biomolecules would further improve clinical outcomes. 
Table 1 Efficacy of various stem cell populations/carriers in small preclinical tendon defect models

\begin{tabular}{|c|c|c|c|c|}
\hline Experimental details & $\begin{array}{l}\text { Accelerated } \\
\text { tendon healing }\end{array}$ & $\begin{array}{l}\text { Enhanced } \\
\text { tendon strength }\end{array}$ & $\begin{array}{l}\text { Improved } \\
\text { tendon } \\
\text { histology }\end{array}$ & Reference \\
\hline Allogeneic BMSCs with fibrin hydrogel Rabbit Achilles or rat patellar tendon & $x$ & $\checkmark$ & $\checkmark$ & [126-128] \\
\hline Autologous ADSCs with PRP hydrogel Rabbit Achilles tendon & $\checkmark$ & $\checkmark$ & $\checkmark$ & [61] \\
\hline Autologous BMSCs with collagen I hydrogel Rabbit Achilles tendon & $x$ & $\checkmark$ & $\checkmark$ & [55] \\
\hline Autologous BMSCs with PLGA sheet Rabbit rotator cuff tendon & $\checkmark$ & $\checkmark$ & $\checkmark$ & [115] \\
\hline Allogeneic ACL-derived CD34+ cell sheet with tendon graft Rat $\mathrm{ACL}$ & $\checkmark$ & $\checkmark$ & $\checkmark$ & [81] \\
\hline $\begin{array}{l}\text { Autologous ADSCs with heparin, fibrin and PDGF BB hydrogel on electro- } \\
\text { spun PLGA Dog flexor digitorum profundus tendon }\end{array}$ & & & $\checkmark$ & [119] \\
\hline Embryonic stem cell sheets Rat patellar tendon & $\checkmark$ & $\checkmark$ & $\checkmark$ & [129] \\
\hline Induced pluripotent stem cells and fibrin gel Rat patellar tendon & $\checkmark$ & $\checkmark$ & $\checkmark$ & [130] \\
\hline TSC sheet Rat patellar tendon & $\checkmark$ & $\checkmark$ & $\checkmark$ & [131] \\
\hline Engineered BMSCs on collagen scaffold Rat Achilles tendon & $\checkmark$ & $\checkmark$ & $\checkmark$ & [132-134] \\
\hline
\end{tabular}

A tick indicates a positive outcome and a cross indicates a negative/suboptimal improvement compared to control. Entries are blank when the study did not assess the parameter mentioned. ACL, anterior cruciate ligament; ADSC, adipose-derived stem cell; BMSC, bone marrow-derived mesenchymal stem cell; PDGF BB, platelet derived growth factor BB; PLGA, polylactide-co-glycolide; PRP, platelet rich plasma; TSC, tendon stem cell.

\section{Conclusions and future perspectives}

Stem cell-based tendon tissue engineering is an increasingly vibrant research area that continues to witness growing interest in many aspects. Although tendons develop fibrocartilage and ossification in response to injury [120] and BMSC implantation has resulted in ectopic bone formation in mouse [121], rat [122] and rabbit [123-125] models, overwhelming preclinical results in small animal models demonstrate improved tendon healing, biomechanics and histological characteristics (Table 1). Whether these results can be reproduced in large animal models, which are subject to similar forces to humans and will therefore allow acquisition of more clinically relevant data, will have to be seen.

This review clearly indicates that BMSCs and ADSCs are leading contenders for a suitable stem cell population for tendon repair. This may be further confirmed by currently running clinical trials (ClinicalTrials.gov identifier NCT01856140 - allogeneic ADSC injection; ClinicalTrials.gov identifier NCT01687777 - autologous BMSCs with collagen type I membrane). Very few studies have been conducted with embryonic stem cells [129], induced pluripotent stem cells [130], perivascular stem cells $[135,136]$, TSCs $[121,131,137]$ and engineered cells [132-134], despite the fact that all have shown promising results in vitro and in vivo. Should their efficacy be proven consistently in other clinical targets, it is certain that their potential will be studied in a more systematic fashion in tendon and ligament repair.

Among the biomaterial-based stem cell carriers, injectable hydrogels for small defects and anisotropic scaffolds for large defects are the primary focus of scientific research. We speculate that difficulties in recellularising tendon grafts, due to the compact tissue structure, prohibits extensive research in the area. Cell-sheet tissue engineering or tissue engineering by self-assembly strategies have just started taking off in tendon repair. If in vitro microenvironment modulators can be developed to enhance matrix production, to maintain cell phenotype for the duration of the device manufacturing, and to provide adequate mechanical properties [138-141], such technologies are anticipated to lead academic, clinical and industrial research in the years to come.

\section{Abbreviations \\ ACL: Anterior cruciate ligament; ADSC: Adipose tissue-derived stem cell; BMSC: Bone marrow-derived mesenchymal stem cell; PRP: Platelet rich plasma; TSC: Tendon stem cell.}

\section{Competing interests}

The authors declare that they have no competing interests.

\section{Author' information}

Sunny Akogwu Abbah and Kyriakos Spanoudes are joint first authorship.

\section{Acknowledgments}

The authors would like to thank Maciek Doczyk (http://doczykdesign.com) for his support in the preparation of the figure in this manuscript. DIZ would like to acknowledge financial support from: the European Union Seventh Framework Programme (FP7/2007-2013), under grant agreement number 251385 (Tendon Regeneration); the Collaborative Centre for Applied Nanotechnology (CCAN) as part of the Enterprise Ireland and IDA Ireland Technology Centres Programme, under grant agreement number CC-20080509 (2D3D); the Science Foundation Ireland, Research Frontiers Programme, under grant agreement number 09/RFP/ENM2483; and the Health Research Board, Health Research Awards Programme, under grant agreement number HRA_POR/2011/84.

\section{Author details}

${ }^{1}$ Network of Excellence for Functional Biomaterials (NFB), Bioscience Building, National University of Ireland Galway (NUI Galway), Galway, Ireland.

${ }^{2}$ Regenerative Medicine Institute (REMEDI), Bioscience Building, National University of Ireland Galway (NUI Galway), Galway, Ireland. 


\section{References}

1. Sharma P, Maffulli N: Biology of tendon injury: healing, modeling and remodeling. J Musculoskelet Neuronal Interact 2006, 6:181-190.

2. Maffulli N, Wong J, Almekinders LC: Types and epidemiology of tendinopathy. Clin Sports Med 2003, 22:675-692

3. Zeugolis DI, Chan JCY, Pandit A: Tendons: engineering of functional tissues. In Tissue Engineering. Edited by Pallua N, Suscheck CV. Berlin, Heidelberg: Springer; 2011:537-572.

4. Zeugolis DI, Keeney M, Collin E, Fontana G, Pandit A: Xenogenic tissues and biomaterials for the skeletal system. In Comprehensive Biomaterials. Volume 2. Edited by Ducheyne P, Healy KE, Hutmacher DW, Grainger DW, Kirkpatrick CJ. Oxford: Elsevier; 2011:387-404.

5. Moller A, Astron M, Westlin N: Increasing incidence of Achilles tendon rupture. Acta orthopaedica Scandinavica 1996, 67:479-481.

6. Bullough R, Finnigan T, Kay A, Maffulli N, Forsyth N: Tendon repair through stem cell intervention: cellular and molecular approaches. Disabil Rehabil 2008, 30:1746-1751.

7. Yin Z, Chen X, Chen J-I, Ouyang H-W: Stem cells for tendon tissue engineering and regeneration. Expert Opin Biol Ther 2010, 10:689-700.

8. Liu C-F, Aschbacher-Smith L, Barthelery NJ, Dyment N, Butler D, Wylie C: What we should know before using tissue engineering techniques to repair injured tendons: a developmental biology perspective. Tissue Eng Part B Rev 2011, 17:165-176.

9. Chen HS, Chen YL, Harn HJ, Lin JS, Lin SZ: Stem cell therapy for tendon injury. Cell Transplant 2013, 22:677-684.

10. Lui PP, Ng SW: Cell therapy for the treatment of tendinopathy - a systematic review on the pre-clinical and clinical evidence. Semin Arthritis Rheum 2013, 42:651-666.

11. Wang JCY: Evaluating therapeutic efficacy against cancer stem cells: new challenges posed by a new paradigm. Cell Stem Cell 2007, 1:497-501.

12. Sasportas LS, Kasmieh $\mathrm{R}$, Wakimoto $\mathrm{H}$, Hingtgen $\mathrm{S}$, van de Water JAJM, Mohapatra G, Figueiredo JL, Martuza RL, Weissleder R, Shah K: Assessment of therapeutic efficacy and fate of engineered human mesenchymal stem cells for cancer therapy. Proc Natl Acad Sci U S A 2009, 106:4822-4827.

13. Lee T: Stem cell therapy independent of stemness. World J Stem Cells 2012, 4:120-124

14. Flynn $A$, Chen $X, O^{\prime}$ Connell E, O'Brien T: A comparison of the efficacy of transplantation of bone marrow-derived mesenchymal stem cells and unrestricted somatic stem cells on outcome after acute myocardial infarction. Stem Cell Res Ther 2012, 3:36.

15. Liechty KW, MacKenzie TC, Shaaban AF, Radu A, Moseley AM, Deans R, Marshak DR, Flake AW: Human mesenchymal stem cells engraft and demonstrate site-specific differentiation after in utero transplantation in sheep. Nat Med 2000, 6:1282-1286.

16. Lerou PH, Daley GQ: Therapeutic potential of embryonic stem cells. Blood Rev 2005, 19:321-331.

17. Serakinci N, Keith WN: Therapeutic potential of adult stem cells. Eur J Cancer 2006, 42:1243-1246.

18. Rosova I, Dao M, Capoccia B, Link D, Nolta J: Hypoxic preconditioning results in increased motility and improved therapeutic potential of human mesenchymal stem cells. Stem Cells 2008, 26:2173-2182.

19. Watt FM, Driskell RR: The therapeutic potential of stem cells. Philos Trans $R$ Soc Lond B Biol Sci 2010, 365:155-163.

20. Belema-Bedada F, Uchida S, Martire A, Kostin S, Braun T: Efficient homing of multipotent adult mesenchymal stem cells depends on FROUNTmediated clustering of CCR2. Cell Stem Cell 2008, 2:566-575.

21. Meirelles Lda S, Fontes AM, Covas DT, Caplan Al: Mechanisms involved in the therapeutic properties of mesenchymal stem cells. Cytokine Growth Factor Rev 2009, 20:419-427.

22. Sharma RI, Snedeker JG: Paracrine interactions between mesenchymal stem cells affect substrate driven differentiation toward tendon and bone phenotypes. PLOS One 2012, 7:e31504

23. Matsuda N, Shimizu T, Yamato M, Okano T: Tissue engineering based on cell sheet technology. Adv Mater 2007, 19:3089-3099.

24. Okamoto N, Kushida T, Oe K, Umeda M, Ikehara S, lida H: Treating Achilles tendon rupture in rats with bone-marrow-cell transplantation therapy. J Bone Joint Surg Am 2010, 92:2776-2784.

25. van Ramshorst J, Rodrigo S, Schalij M, Beeres S, Bax J, Atsma D: Bone marrow cell injection for chronic myocardial ischemia: the past and the future. J Cardiovasc Trans/ Res 2011, 4:182-191.
26. Cellesi F: Thermoresponsive hydrogels for cellular delivery. Ther Deliv 2012, 3:1395-1407.

27. Richardson LE, Dudhia J, Clegg PD, Smith R: Stem cells in veterinary medicine - attempts at regenerating equine tendon after injury. Trends Biotechnol 2007, 25:409-416.

28. Smith RK: Mesenchymal stem cell therapy for equine tendinopathy. Disabil Rehabil 2008, 30:1752-1758.

29. Smith RKW, Korda M, Blunn GW, Goodship AE: Isolation and implantation of autologous equine mesenchymal stem cells from bone marrow into the superficial digital flexor tendon as a potential novel treatment. Equine Vet J 2003, 35:99-102.

30. Pacini S, Spinabella S, Trombi L, Fazzi R, Galimberti S, Dini F, Carlucci F, Petrini M: Suspension of bone marrow-derived undifferentiated mesenchymal stromal cells for repair of superficial digital flexor tendon in race horses. Tissue Eng 2007, 13:2949-2955.

31. Godwin EE, Young NJ, Dudhia J, Beamish IC, Smith RKW: Implantation of bone marrow-derived mesenchymal stem cells demonstrates improved outcome in horses with overstrain injury of the superficial digital flexor tendon. Equine Vet J 2012, 44:25-32.

32. Fan HB, Liu HF, Toh SL, Goh JCH: Anterior cruciate ligament regeneration using mesenchymal stem cells and silk scaffold in large animal model. Biomaterials 2009, 30:4967-4977.

33. Kuo C, Marturano J, Tuan R: Novel strategies in tendon and ligament tissue engineering: advanced biomaterials and regeneration motifs. Sports Med Arthrosc Rehabil Ther Technol 2010, 2:20.

34. Butler DL, Gooch C, Kinneberg KRC, Boivin GP, Galloway MT, Nirmalanandhan VS, Shearn JT, Dyment NA, Juncosa-Melvin N: The use of mesenchymal stem cells in collagen-based scaffolds for tissueengineered repair of tendons. Nat Protoc 2010, 5:849-863.

35. Cohen S, Leshansky L, Zussman E, Burman M, Srouji S, Livne E, Abramov N, Itskovitz-Eldor J: Repair of full-thickness tendon injury using connective tissue progenitors efficiently derived from human embryonic stem cells and fetal tissues. Tissue Eng Part A 2010, 16:3119-3137.

36. Shearn JT, Kinneberg KRC, Dyment NA, Galloway MT, Kenter K, Wylie C, Butler DL: Tendon tissue engineering: progress, challenges, and translation to the clinic. J Musculoskelet Neuronal Interact 2011, $11: 163-173$

37. James R, Kumbar SG, Laurencin $C$, Balian G, Chhabra AB: Tendon tissue engineering: adipose-derived stem cell and GDF-5 mediated regeneration using electrospun matrix systems. Biomed Mater 2011, 6:025011.

38. Lee KY, Mooney DJ: Hydrogels for tissue engineering. Chem Rev 2001, 101:1869-1880.

39. Yang Z, Liang G, Ma M, Abbah AS, Lu WW, Xu B: D-glucosamine-based supramolecular hydrogels to improve wound healing. Chem Commun (Camb) 2007:843-845.

40. Abbah SA, Lu WW, Peng SL, Aladin DM, Li ZY, Tam WK, Cheung KM, Luk KD, Zhou GQ: Extracellular matrix stability of primary mammalian chondrocytes and intervertebral disc cells cultured in alginate-based microbead hydrogels. Cell Transplant 2008, 17:1181-1192.

41. Fisher OZ, Khademhosseini A, Langer R, Peppas NA: Bioinspired materials for controlling stem cell fate. Acc Chem Res 2009, 43:419-428.

42. Collin EC, Grad S, Zeugolis DI, Vinatier CS, Clouet JR, Guicheux JJ, Weiss P, Alini M, Pandit AS: An injectable vehicle for nucleus pulposus cell-based therapy. Biomaterials 2011, 32:2862-2870.

43. Burdick JA, Prestwich GD: Hyaluronic acid hydrogels for biomedical applications. Adv Mater 2011, 23:H41-H56.

44. Munarin F, Petrini P, Bozzini S, Tanzi M: New perspectives in cell delivery systems for tissue regeneration: natural-derived injectable hydrogels. J Appl Biomater Funct Mater 2012, 10:67-81.

45. Aguado BA, Mulyasasmita W, Su J, Lampe KJ, Heilshorn SC: Improving viability of stem cells during syringe needle flow through the design of hydrogel cell carriers. Tissue Eng Part A 2012, 18:806-815.

46. Rizzi R, Bearzi C, Mauretti A, Bernardini S, Cannata S, Gargioli C: Tissue engineering for skeletal muscle regeneration. Muscles Ligaments Tendons J 2012, 2:230-234.

47. Vemula P, Wiradharma N, Ankrum J, Miranda O, John G, Karp J: Prodrugs as self-assembled hydrogels: a new paradigm for biomaterials. Curr Opin Biotechnol 2013, 24:1174-1182.

48. Friess W: Collagen - biomaterial for drug delivery. Eur J Pharm Biopharm 1998, 45:113-136.

49. Clark RAF: Fibrin and wound healing. Ann N Y Acad Sci 2001, 936:355-367. 
50. Jackson M: Fibrin sealants in surgical practice: an overview. Am J Surg 2001, 182:1s-7s.

51. Ahmed T, Dare E, Hincke M: Fibrin: a versatile scaffold for tissue engineering applications. Tissue Eng Part B Rev 2008, 14:199-215.

52. Zeugolis DI, Raghunath M: Collagen: materials analysis and implant uses. In Comprehensive Biomaterials. Volume 2. Edited by Ducheyne P, Healy KE, Hutmacher DW, Grainger DW, Kirkpatrick CJ. Oxford: Elsevier; 2011:261-278

53. Rodeo SA, Delos D, Williams RJ, Adler RS, Pearle A, Warren RF: The effect of platelet-rich fibrin matrix on rotator cuff tendon healing: a prospective, randomized clinical study. Am J Sports Med 2012, 40:1234-1241.

54. He M, Gan AW, Lim AY, Goh JC, Hui JH, Lee EH, Chong AK: The effect of fibrin glue on tendon healing and adhesion formation in a rabbit model of flexor tendon injury and repair. J Plast Surg Hand Surg 2013, 47:509-512.

55. Awad HA, Butler DL, Boivin GP, Smith FN, Malaviya P, Huibregtse B, Caplan Al: Autologous mesenchymal stem cell-mediated repair of tendon. Tissue Eng 1999, 5:267-277.

56. Juncosa-Melvin N, Boivin GP, Galloway MT, Gooch C, West JR, Butler DL: Effects of cell-to-collagen ratio in stem cell-seeded constructs for Achilles tendon repair. Tissue Eng 2006, 12:681-689.

57. Wu L, Li M, Zhao J, Chen D, Zhou Z: [Preliminary study on polyvinyl alcohol/wild antheraea pernyi silk fibroin as nanofiber scaffolds for tissue engineered tendon]. Zhongguo Xiu Fu Chong Jian Wai Ke Za Zhi 2011, 25:181-186.

58. Wu W, Zhang J, Dong Q, Liu Y, Mao T, Chen F: Platelet-rich plasma - a promising cell carrier for micro-invasive articular cartilage repair. Med Hypotheses 2009, 72:455-457.

59. Mazzocca AD, McCarthy MB, Chowaniec DM, Dugdale EM, Hansen D, Cote MP, Bradley JP, Romeo AA, Arciero RA, Beitzel K: The positive effects of different platelet-rich plasma methods on human muscle, bone, and tendon cells. Am J Sports Med 2012, 40:1742-1749.

60. Boswell SG, Cole BJ, Sundman EA, Karas V, Fortier LA: Platelet-rich plasma: a milieu of bioactive factors. Arthroscopy 2012, 28:429-439.

61. Uysal CA, Tobita M, Hyakusoku H, Mizuno $\mathrm{H}$ : Adipose-derived stem cells enhance primary tendon repair: biomechanical and immunohistochemical evaluation. J Plast Reconstr Aesthet Surg 2012, 65:1712-1719.

62. Chen L, Dong S-W, Liu J-P, Tao X, Tang K-L, Xu J-Z: Synergy of tendon stem cells and platelet-rich plasma in tendon healing. J Orthopaed Res 2012, 30:991-997.

63. Molloy T, Wang Y, Murrell GAC: The roles of growth factors in tendon and ligament healing. Sports Med 2003, 33:381-394.

64. Kashiwagi K, Mochizuki Y, Yasunaga Y, Ishida O, Deie M, Ochi M: Effects of transforming growth factor-beta 1 on the early stages of healing of the achilles tendon in a rat model. Scand J Plast Reconstr Surg Hand Surg 2004, 38:193-197.

65. Kawamura K, Chu CR, Sobajima S, Robbins PD, Fu FH, Izzo NJ, Niyibizi C: Adenoviral-mediated transfer of TGF- $\beta 1$ but not IGF-1 induces chondrogenic differentiation of human mesenchymal stem cells in pellet cultures. Exp Hematol 2005, 33:865-872.

66. Xu YH, Murrell GAC: The basic science of tendinopathy. Clin Orthopaed Related Res 2008, 466:1528-1538.

67. Rui YF, Lui PPY, Chan LS, Chan KM, Fu SC, Li G: Does erroneous differentiation of tendon-derived stem cells contribute to the pathogenesis of calcifying tendinopathy? Chinese Med J (Engl) 2011, 124:606-610.

68. Holladay C, Abbah SA, O'Dowd C, Pandit A, Zeugolis D: Preferential tendon stem cell response to growth factor supplementation. J Tissue Eng Regen Med 2014. in press.

69. Stanco D, Vigano M, Croiset S, de Girolamo L: Applications and limits of platelet-rich plasma in sports related injuries. J Biol Regul Homeost Agents 2012, 26:53s-61s.

70. Malhotra A, Pelletier M, Yu Y, Walsh W: Can platelet-rich plasma (PRP) improve bone healing? A comparison between the theory and experimental outcomes. Arch Orthop Trauma Surg 2013, 133:153-165.

71. Jiang D, Wang J: Tendinopathy and its treatment with platelet-rich plasma (PRP). Histol Histopathol 2013, 28:1537-1546.

72. Wroblewski AP, Mejia HA, Wright VJ: Application of platelet-rich plasma to enhance tissue repair. Operative Techniques Orthopaed 2010, 20:98-105.

73. Kon E, Filardo G, Martino AD, Marcacci M: Platelet-rich plasma (PRP) to treat sports injuries: evidence to support its use. Knee Surg Sports Traumatol Arthrosc 2011, 19:516-527.
74. McCarrel TM, Minas T, Fortier LA: Optimization of leukocyte concentration in platelet-rich plasma for the treatment of tendinopathy. J Bone Joint Surg Am 2012, 94:e143. 141-148.

75. Chen JM, Xu JK, Wang AL, Zheng MH: Scaffolds for tendon and ligament repair: review of the efficacy of commercial products. Exp Rev Med Devices 2009, 6:61-73.

76. Kryger GS, Chong AK, Costa M, Pham H, Bates SJ, Chang J: A comparison of tenocytes and mesenchymal stem cells for use in flexor tendon tissue engineering. J Hand Surg Am 2007, 32:597-605.

77. Soon M, Hassan A, Hui J, Goh J, Lee E: An analysis of soft tissue allograft anterior cruciate ligament reconstruction in a rabbit model: a short-term study of the use of mesenchymal stem cells to enhance tendon osteointegration. Am J Sports Med 2007, 35:962-971.

78. Lui $P$, Zhang $P$, Chan $K$, Qin L: Biology and augmentation of tendon-bone insertion repair. J Orthop Surg Res 2010, 5:1-14.

79. Ju Y, Muneta T, Yoshimura H, Koga H, Sekiya I: Synovial mesenchymal stem cells accelerate early remodeling of tendon-bone healing. Cell Tissue Res 2008, 332:469-478.

80. Mifune Y, Matsumoto T, Ota S, Nishimori M, Usas A, Kopf S, Kuroda R, Kurosaka M, Fu FH, Huard J: Therapeutic potential of anterior cruciate ligament-derived stem cells for anterior cruciate ligament reconstruction Cell Transplant 2012, 21:1651-1665.

81. Mifune Y, Matsumoto T, Takayama K, Terada S, Sekiya N, Kuroda R, Kurosaka M, Fu FH, Huard J: Tendon graft revitalization using adult anterior cruciate ligament ( $\mathrm{ACL}$ )-derived $\mathrm{CD} 34+$ cell sheets for $\mathrm{ACL}$ reconstruction. Biomaterials 2013, 34:5476-5487.

82. Zhang J, Li B, Wang JH: The role of engineered tendon matrix in the stemness of tendon stem cells in vitro and the promotion of tendon-like tissue formation in vivo. Biomaterials 2011, 32:6972-6981.

83. Yin Z, Chen $X$, Zhu T, Hu JJ, Song HX, Shen WL, Jiang LY, Heng BC, Ji JF, Ouyang HW: The effect of decellularized matrices on human tendon stem/progenitor cell differentiation and tendon repair. Acta Biomater 2013, 9:9317-9329

84. Yang G, Rothrauff BB, Lin H, Gottardi R, Alexander PG, Tuan RS: Enhancement of tenogenic differentiation of human adipose stem cells by tendon-derived extracellular matrix. Biomaterials 2013 [Epub ahead of print].

85. Ichioka S, Harii K, Yamada A, Sugiura Y: Tendinocutaneous free flap transfer to cover an extensive skin-tendon defect of the dorsum of the hand: case report. J Trauma 1994, 36:901-903.

86. Adani R, Marcoccio I, Tarallo L: Flap coverage of dorsum of hand associated with extensor tendons injuries: a completely vascularized single-stage reconstruction. Microsurgery 2003, 23:32-39.

87. Kim SW, Hong JP, Lee WJ, Chung YK, Tark KC: Single-stage Achilles tendon reconstruction using a composite sensate free flap of dorsalis pedis and tendon strips of the extensor digitorum longus in a complex wound. Ann Plast Surg 2003, 50:653-657.

88. Bora FW Jr, Osterman AL, Thomas VJ, Maitin EC, Polineni S: The treatment of ruptures of multiple extensor tendons at wrist level by a free tendon graft in the rheumatoid patient. J Hand Surg Am 1987, 12:1038-1040.

89. Mountney J, Blundell CM, McArthur P, Stanley D: Free tendon interposition grafting for the repair of ruptured extensor tendons in the rheumatoid hand. A clinical and biomechanical assessment. J Hand Surg Br 1998, 23:662-665.

90. Nakamura S, Katsuki M: Tendon grafting for multiple extensor tendon ruptures of fingers in rheumatoid hands. J Hand Surg Br 2002, 27:326-328

91. Chu PJ, Lee HM, Hou YT, Hung ST, Chen JK, Shih JT: Extensor-tendons reconstruction using autogenous palmaris longus tendon grafting for rheumatoid arthritis patients. J Orthop Surg 2008, 3:16.

92. Oka Y: Reconstruction of the flexor pollicis longus tendon ruptured, but untreated, during infancy. Tokai J Exp Clin Med 2000, 25:23-26.

93. Wajid MA, Rangan A: Congenital aplasia or hypoplasia of extensor tendons of the hand - a case report and review of the literature. J R Coll Surg Edinb 2001, 46:57-58.

94. Kannus P: Structure of the tendon connective tissue. Scand J Med Sci Sports 2000, 10:312-320.

95. Rhee SH, Suetsugu Y, Tanaka J: Biomimetic configurational arrays of hydroxyapatite nanocrystals on bio-organics. Biomaterials 2001, 22:2843-2847. 
96. Jarvinen $T$, Jarvinen $T$, Kannus $P$, Jozsa $L$, Jarvinen M: Collagen fibres of the spontaneously ruptured human tendons display decrease thickness and crimp angle. J Orthopaed Res 2004, 22:1303-1309.

97. Towler DA, Gelberman $\mathrm{RH}$ : The alchemy of tendon repair: a primer for the (S)mad scientist. J Clin Invest 2006, 116:863-866.

98. Lippiello L: Collagen synthesis in tenocytes, ligament cells and chondrocytes exposed to a combination of glucosamine $\mathrm{HCl}$ and chondroitin sulfate. eCAM 2007, 4:219-224.

99. Kato YP, Dunn MG, Zawadsky JP, Tria AJ, Silver FH: Regeneration of Achilles tendon with a collagen tendon prosthesis. Results of a one-year implantation study. J Bone Joint Surg Am 1991, 73:561-574.

100. Cavallaro JF, Kemp PD, Kraus KH: Collagen fabrics as biomaterials. Biotechnol Bioeng 1994, 43:781-791.

101. Cornwell KG, Downing B, Pins GD: Characterizing fibroblast migration on discrete collagen threads for applications in tissue regeneration. J Biomed Mater Res Part A 2004, 71A:55-62.

102. Kew SJ, Gwynne JH, Enea D, Abu-Rub M, Pandit A, Zeugolis D, Brooks RA, Rushton N, Best SM, Cameron RE: Regeneration and repair of tendon and ligament tissue using collagen fibre biomaterials. Acta Biomater 2011, 7:3237-3247.

103. Enea D, Gwynne J, Kew S, Arumugam M, Shepherd J, Brooks R, Ghose S, Best S, Cameron R, Rushton N: Collagen fibre implant for tendon and ligament biological augmentation. In vivo study in an ovine model. Knee Surg Sports Traumatol Arthrosc 2013, 21:1783-1793.

104. Cheng X, Gurkan UA, Dehen CJ, Tate MP, Hillhouse HW, Simpson GJ, Akkus O: An electrochemical fabrication process for the assembly of anisotropically oriented collagen bundles. Biomaterials 2008, 29:3278-3288.

105. Abu-Rub MT, Billiar KL, van Es MH, Knight A, Rodriguez BJ, Zeugolis DI, McMahon S, Windebank AJ, Pandit A: Nano-textured self-assembled aligned collagen hydrogels promote directional neurite guidance and overcome inhibition by myelin associated glycoprotein. Soft Matter 2011, 7:2770-2781.

106. Kishore V, Paderi JE, Akkus A, Smith KM, Balachandran D, Beaudoin S, Panitch A, Akkus O: Incorporation of a decorin biomimetic enhances the mechanical properties of electrochemically aligned collagen threads. Acta Biomater 2011, 7:2428-2436.

107. Kardestuncer T, McCarthy MB, Karageorgiou V, Kaplan D, Gronowicz G: RGD-tethered silk substrate stimulates the differentiation of human tendon cells. Clin Orthopaed Related Res 2006, 448:234-239.

108. Sahoo S, Ang L-T, Cho-Hong Goh J, Toh S-L: Bioactive nanofibers for fibroblastic differentiation of mesenchymal precursor cells for ligament/tendon tissue engineering applications. Differentiation 2010, 79:102-110.

109. Yin Z, Chen X, Chen JL, Shen WL, Hieu Nguyen TM, Gao L, Ouyang HW: The regulation of tendon stem cell differentiation by the alignment of nanofibers. Biomaterials 2010, 31:2163-2175.

110. Xu L, Cao D, Liu W, Zhou G, Zhang WJ, Cao Y: In vivo engineering of a functional tendon sheath in a hen model. Biomaterials 2010, 31:3894-3902

111. Vaquette C, Kahn C, Frochot C, Nouvel C, Six JL, De Isla N, Luo LH, Cooper-White J, Rahouadj R, Wang X: Aligned poly(L-lactic-co-e-caprolactone) electrospun microfibers and knitted structure: a novel composite scaffold for ligament tissue engineering. J Biomed Mater Res A 2010, 94:1270-1282.

112. English A, Azeem A, Gaspar DA, Keane K, Kumar P, Keeney M, Rooney N, Pandit A, Zeugolis DI: Preferential cell response to anisotropic electro-spun fibrous scaffolds under tension-free conditions. J Mater Sci-Mater M 2012, 23:137-148.

113. Yang L, Fitie CFC, van der Werf KO, Bennink ML, Dijkstra PJ, Feijen J: Mechanical properties of single electrospun collagen type I fibers. Biomaterials 2008, 29:955-962.

114. Zeugolis DI, Khew ST, Yew ESY, Ekaputra AK, Tong YW, Yung L-YL, Hutmacher DW, Sheppard C, Raghunath M: Electro-spinning of pure collagen nano-fibres - just an expensive way to make gelatin? Biomaterials 2008, 29:2293-2305.

115. Yokoya S, Mochizuki Y, Natsu K, Omae H, Nagata Y, Ochi M: Rotator cuff regeneration using a bioabsorbable material with bone marrow-derived mesenchymal stem cells in a rabbit model. Am J Sports Med 2012, 40:1259-1268.

116. Ouyang HW, Goh JC, Thambyah A, Teoh SH, Lee EH: Knitted poly-lactideco-glycolide scaffold loaded with bone marrow stromal cells in repair and regeneration of rabbit Achilles tendon. Tissue Eng 2003, 9:431-439.

117. Young RG, Butler DL, Weber W, Caplan Al, Gordon SL, Fink DJ: Use of mesenchymal stem cells in a collagen matrix for Achilles tendon repair. J Orthop Res 1998, 16:406-413.
118. Awad HA, Boivin GP, Dressler MR, Smith FN, Young RG, Butler DL: Repair of patellar tendon injuries using a cell-collagen composite. J Orthop Res 2003, 21:420-431.

119. Manning CN, Schwartz AG, Liu W, Xie J, Havlioglu N, Sakiyama-Elbert SE, Silva MJ, Xia Y, Gelberman RH, Thomopoulos S: Controlled delivery of mesenchymal stem cells and growth factors using a nanofiber scaffold for tendon repair. Acta Biomater 2013, 9:6905-6914.

120. Fenwick S, Harrall R, Hackney R, Bord S, Horner A, Hazleman B, Riley G: Endochondral ossification in Achilles and patella tendinopathy. Rheumatology 2002, 41:474-476.

121. Bi Y, Ehirchiou D, Kilts TM, Inkson CA, Embree MC, Sonoyama W, Li L, Leet Al, Seo BM, Zhang L, Shi S, Young MF: Identification of tendon stem/progenitor cells and the role of the extracellular matrix in their niche. Nat Med 2007, 13:1219-1227.

122. Pietschmann M, Frankewycz B, Schmitz P, Docheva D, Sievers B, Jansson V, Schieker M, Müller P: Comparison of tenocytes and mesenchymal stem cells seeded on biodegradable scaffolds in a full-size tendon defect model. J Mater Sci Mater Med 2013, 24:211-220.

123. Harris M, Butler D, Boivin G, Florer J, Schantz E, Wenstrup R: Mesenchymal stem cells used for rabbit tendon repair can form ectopic bone and express alkaline phosphatase activity in constructs. J Orthop Res 2004, 22:998-1003.

124. Awad HA, Boivin GP, Dressler MR, Smith FN, Young RG, Butler DL: Repair of patellar tendon injuries using a cell-collagen composite. J Orthop Res 2003, 21:420-431.

125. Dressler M, Butler D, Boivin G: Effects of age on the repair ability of mesenchymal stem cells in rabbit tendon. J Orthop Res 2005, 23:287-293.

126. Chong AK, Ang AD, Goh JC, Hui JH, Lim AY, Lee EH, Lim BH: Bone marrowderived mesenchymal stem cells influence early tendon-healing in a rabbit achilles tendon model. J Bone Joint Surg Am 2007, 89:74-81.

127. Hankemeier S, van Griensven M, Ezechieli M, Barkhausen T, Austin M, Jagodzinski M, Meller R, Bosch U, Krettek C, Zeichen J: Tissue engineering of tendons and ligaments by human bone marrow stromal cells in a liquid fibrin matrix in immunodeficient rats: results of a histologic study. Arch Orthop Trauma Surg 2007, 127:815-821.

128. Hankemeier S, Hurschler C, Zeichen J, van Griensven M, Miller B, Meller R, Ezechieli M, Krettek C, Jagodzinski M: Bone marrow stromal cells in a liquid fibrin matrix improve the healing process of patellar tendon window defects. Tissue Eng Part A 2009, 15:1019-1030.

129. Chen X, Song X-H, Yin Z, Zou X-H, Wang L-L, Hu H, Cao T, Zheng M, Ouyang HW: Stepwise differentiation of human embryonic stem cells promotes tendon regeneration by secreting fetal tendon matrix and differentiation factors. Stem Cells 2009, 27:1276-1287.

130. Xu W, Wang Y, Liu E, Sun Y, Luo Z, Xu Z, Liu W, Zhong L, Lv Y, Wang A, Tang Z, Li S, Yang L: Human iPSC-derived neural crest stem cells promote tendon repair in a rat patellar tendon window defect model. Tissue Eng Part A 2013, 19:2439-2451.

131. Ni M, Rui YF, Tan Q, Liu Y, Xu LL, Chan KM, Wang Y, Li G: Engineered scaffold-free tendon tissue produced by tendon-derived stem cells. Biomaterials 2013, 34:2024-2037.

132. Hoffmann A, Pelled G, Turgeman G, Eberle P, Zilberman $Y$, Shinar $H$, Keinan-Adamsky K, Winkel A, Shahab S, Navon G, Gross G, Gazit D: Neotendon formation induced by manipulation of the Smad8 signalling pathway in mesenchymal stem cells. J Clin Invest 2006, 116:940-952.

133. Ben-Arav A, Snedeker JG, Zilberman Y, Gazit Z, Muller R, Pelled G, Gazit D: Smad8/BMP-2 engineered mesenchymal stem cells induce rapid Achilles tendon full defect regeneration. Mol Ther 2009, 17:S267-S267.

134. Pelled G, Snedeker JG, Ben-Arav A, Rigozzi S, Zilberman Y, Kimelman-Bleich N, Gazit Z, Muller R, Gazit D: Smad8/BMP2-engineered mesenchymal stem cells induce accelerated recovery of the biomechanical properties of the Achilles tendon. J Orthop Res 2012, 30:1932-1939.

135. Matsumoto T, Ingham SM, Mifune Y, Osawa A, Logar A, Usas A, Kuroda R, Kurosaka M, Fu FH, Huard J: Isolation and characterization of human anterior cruciate ligament-derived vascular stem cells. Stem Cells Dev 2012, 21:859-872.

136. Tempfer H, Gehwolf R, Wagner A, Resch H, Rivera FJ, Aigner A, Bauer HC, Lehner C: Human tendon perivascular cells are multipotent and express embryonic stem cell associated markers. J Tissue Eng Regen Med 2012, 6:249-249

137. Randelli P, Conforti E, Piccoli M, Ragone V, Creo P, Cirillo F, Masuzzo P, Tringali C, Cabitza P, Tettamanti G, Gagliano N, Anastasia L: Isolation and 
characterization of 2 new human rotator cuff and long head of biceps tendon cells possessing stem cell-like self-renewal and multipotential differentiation capacity. Am J Sports Med 2013, 41:1653-1664.

138. Lutolf MP, Gilbert PM, Blau HM: Designing materials to direct stem-cell fate. Nature 2009, 462:433-441.

139. Keung AJ, Kumar S, Schaffer DV: Presentation counts: microenvironmental regulation of stem cells by biophysical and material cues. Annu Rev Cell Dev Biol 2010, 26:533-556.

140. Huang TF, Yew TL, Chiang ER, Ma HL, Hsu CY, Hsu SH, Hsu YT, Hung SC: Mesenchymal stem cells from a hypoxic culture improve and engraft achilles tendon repair. Am J Sports Med 2013, 41:1117-1125.

141. Cigognini D, Lomas A, Kumar P, Satyam A, English A, Azeem A, Pandit A, Zeugolis D: Engineering in vitro microenvironments for cell based therapies and drug discovery. Drug Discov Today 2013, 18:1099-1108.

$10.1186 /$ scrt426

Cite this article as: Abbah et al:: Assessment of stem cell carriers for tendon tissue engineering in pre-clinical models. Stem Cell Research \& Therapy 2014, 5:38 